University of Nebraska - Lincoln

DigitalCommons@University of Nebraska - Lincoln

Publications, Agencies and Staff of the U.S.

Department of Commerce

U.S. Department of Commerce

January 2013

Prioritizing Pacific Salmon Stocks for Conservation: Response to Allendorf et al.

Thomas C. Wainwright

Northwest Fisheries Science Center, Thomas.Wainwright@NOAA.gov

Robin Waples

NOAA, robin.waples@noaa.gov

Follow this and additional works at: https://digitalcommons.unl.edu/usdeptcommercepub

Wainwright, Thomas C. and Waples, Robin, "Prioritizing Pacific Salmon Stocks for Conservation: Response to Allendorf et al." (2013). Publications, Agencies and Staff of the U.S. Department of Commerce. 434.

https://digitalcommons.unl.edu/usdeptcommercepub/434

This Article is brought to you for free and open access by the U.S. Department of Commerce at DigitalCommons@University of Nebraska - Lincoln. It has been accepted for inclusion in Publications, Agencies and Staff of the U.S. Department of Commerce by an authorized administrator of DigitalCommons@University of Nebraska - Lincoln. 


\title{
Prioritizing Pacific Salmon Stocks for Conservation: Response to Allendorf et al.
}

\author{
THOMAS C. WAINWRIGH'T* AND ROBIN S. WAPLES \\ Conservation Biology Division, Northwest Fisheries Science Center, National Marine Fisheries Service, \\ 2725 Montlake Boulevard East, Seattle, WA 98112, U.S.A.
}

Recently, Allendorf et al. (1997) proposed criteria intended to guide prioritization of Pacific salmon (Oncorbynchus spp.) stocks for conservation. The authors provide a good summary of several important aspects of extinction risk, and we agree with many of their points: (1) prioritization is useful and may help focus conservation efforts; (2) a two-pronged approach that identifies the relative risk faced by different populations and evaluates their significance is a reasonable strategy; (3) risks should be evaluated based on multiple criteria; and (4) specific threshold values for these criteria promote objectivity and can assist in decision making. We also recognize the considerable experience of the authors and the many important contributions they have made, individually and collectively, to the biology and conservation of salmon. We don't believe, however, that their prioritization method is entirely workable, and we are concerned that their criteria ignore some major conservation issues for Pacific salmon. We are also concerned that, no doubt unintentionally, their paper gives the mistaken impression that evaluating risk for salmon populations is a straightforward process. This is far from the case for two reasons. First, scientific understanding of processes leading to extinction is limited, especially for salmonids, which have complex life-history strategies and a potentially strong metapopulation structure. Second, as the authors note, the quantity and quality of data relating to risk is quite variable among Pacific salmon populations, with fundamental data on population abundance and trends lacking for many populations.

For the past several years, the Conservation Biology Division of the Northwest Fisheries Science Center has had the lead role within the National Marine Fisheries Service (NMFS) in evaluating the status of anadromous Oncorbynchus spp. with respect to the U.S. Endangered Species

\footnotetext{
${ }^{*}$ Current address: Fishery Analysis and Monitoring Division, Northwest Fisheries Science Center, National Marine Fisheries Service, 2030 South Marine Science Drive, Newport, OR 97365, U.S.A., email Thomas.Wainwright@NOAA.gov

Paper submitted September 29, 1997; revised manuscript accepted April 22, 1998.
}

1144
Act (ESA). The ESA listing process differs somewhat from the prioritization process Allendorf et al. discuss; for example, our evaluations focus on evolutionarily significant units (ESUs) of salmon, which are generally larger units than the "stocks" considered by Allendorf et al. Furthermore, instead of prioritizing ESUs according to relative risk, we focus on determining whether they are presently in danger of extinction or are likely to become endangered in the future-roughly the ESA's definition of endangered and threatened species, respectively. Still, the biological considerations defining risk and significance should be similar in the two processes.

Our comments focus on the assessment of extinction risk rather than other factors Allendorf et al. consider in developing their prioritization. We should emphasize that an important first step in developing a conservation framework is to identify biologically meaningful conservation units. This is a complex issue for Pacific salmon, for which individual spawning populations link into larger metapopulations, and groups of metapopulations form larger clusters (Waples 1995). There is no single hierarchical level that is always the most appropriate for focusing conservation efforts. The ESUs for salmon identified under the ESA are typically larger and more inclusive than the genetic diversity units or gene conservation groups identified under state plans in Washington and Oregon (Kostow 1995; WDFW 1997), but all three frameworks can contribute substantially to conservation. Local conservation efforts can focus on individual stocks, the only level considered by Allendorf et al. A comprehensive conservation program is unlikely to be effective, however, unless it also considers the relationships among the various hierarchical levels and their component populations. This perspective is largely absent from the paper by Allendorf et al.

\section{Omissions}

The approach to risk evaluation presented by Allendorf et al. focuses on relatively few factors and fails to provide a 
complete picture of population health. Other factors that should be considered in overall risk evaluations include disease prevalence, predation, changes in life-history characteristics such as spawning age or size, and directional genetic changes caused by harvest or habitat modification. Such factors may be important for individual populations, and there should be a mechanism to allow their consideration. For example, our ESA status review for west coast coho salmon (O. kisutch) concluded that a sharp decline in adult body size was a significant concern for the Puget Sound ESU (Weitkamp et al. 1995).

The most serious omission is that in their criteria for assessing extinction risk, Allendorf et al. make no mention of hatchery fish. Factors associated with artificial propagation that should be considered in any comprehensive risk assessment for salmon stocks include ecological effects (competition, predation, disease transfer), loss of fitness of natural populations, loss of genetic diversity, and complications in assessing risk to naturally spawning populations that are of mixed wild and hatchery origin (Allendorf \& Ryman 1987; Hindar et al. 1991; Hard et al. 1992; Busack \& Currens 1995).

Special attention must be paid to risks arising from artificial propagation because often they are not reflected in traditional indices of population health. Most risk factors (e.g., habitat degradation, overharvest, hydroelectric power development) directly affect population abundance and trends, but the same is not true of artificial propagation. In fact, hatchery production may mask declines in natural populations if only raw population abundance data are considered. A true assessment of the viability of natural populations requires information about the contribution of naturally spawning hatchery fish and their effects on long-term productivity and fitness.

We have found that the effects of artificial propagation are among the most difficult and controversial to incorporate into risk analyses for our ESA status reviews. Both direct and indirect evidence indicates that, in general, there is ample reason for concern about the effects of hatchery fish on natural populations, but seldom is there sufficient information to determine the magnitude of the effects or their long-term consequences. Nevertheless, the enormous scale of hatchery programs for anadromous Pacific salmonids guarantees that any risk analysis that ignores artificial propagation will be incomplete.

Allendorf et al. do consider the effects of introductions and stock transfers in evaluating genetic and evolutionary legacy. This factor, however, is assigned only a single point in their prioritization process. As a result, a high priority for recovery could be assigned to a nonnative or heavily introgressed stock. We believe that information about stock histories and genetic lineage should be given more weight in the prioritization process in order to direct conservation attention to vulnerable native populations.

\section{Proposed Criteria}

We have several comments about the main criteria that Allendorf et al. propose for ranking extinction risk.

\section{Probability of Extinction}

In their first criterion, Allendorf et al. place strong emphasis on use of population viability analysis (PVA) to provide quantitative estimates of extinction risk. We are skeptical of their statement (p. 142) that "population viability analysis can place a stock unambiguously in either the A, B, or $\mathrm{C}$ category" (with A-C referring to categories of relative extinction risk). As they note, PVA represents a wide variety of model-based methods for formally predicting risk to populations; it is not a single unambiguous method. Further, the ability of models to predict reality is limited by our lack of full understanding of ecological processes controlling populations and our inability to measure those processes accurately and to incorporate all the relevant processes in a single model. The few salmon PVA models used to date consider only simple demographic factors. We are aware of no existing PVA approaches that could produce an unambiguous risk classification for salmon.

This is not to say that formal PVA is not worth pursuing for Pacific salmon. We, along with others, are working to develop population models that can be used in PVA. Formal modeling is the only way to quantify the interactions among the many factors contributing to risk. Several distinct model formulations, each including different subsets of risk factors, are under development, and these different models will undoubtedly provide somewhat different assessments. It is unlikely that a single salmon dynamics model will achieve broad consensus in the near future. We expect that these approaches will provide only a relative measure of risk for comparing populations and management strategies, not an absolute risk estimate that could unambiguously classify populations or ESUs into specific risk categories. For these reasons, we would not put PVA at the top of the list of factors to be considered; instead, we would place greater emphasis on more empirical evidence of risk from specific factors, such as the other criteria proposed by Allendorf et al. or the categories used by the National Marine Fisheries Society in ESA status reviews (Wainwright \& Kope 1997).

\section{Population Size}

Allendorf et al. propose two population size criteria: effective population size $\left(N_{e}\right)$ and total population size $(N)$. The theory used to derive the criterion for $N_{e}$ assumes a completely closed population, an assumption that will seldom be true for Pacific salmon. In spite of a strong homing tendency, some level of natural straying occurs, and small amounts of gene flow can substantially alleviate in- 
breeding in local spawning populations. No realistic assessment of genetic risk associated with small effective size can be made without considering the metapopulation structure of Pacific salmon. This critical point is not acknowledged or addressed by Allendorf et al.

As developed by Allendorf et al., the second criterion (total population size, $N$ ) provides no additional information beyond the first because the target values for $N$ were obtained by expanding the threshold $N_{e}$ values by a fixed ratio of $N: N_{e}$. If population size is to be treated as a separate criterion (and we believe that it should), an independent rationale for the criterion needs to be developed based on nongenetic factors.

Total population size is important to consider in assessing extinction risk from two perspectives: (1) as a factor influencing the effects of random events on otherwise stable populations-related to the concept of minimum viable populations (MVP; Gilpin \& Soulé 1986) and (2) as a determinant of the time until a declining population reaches critically low numbers, as in the concept of "driven extinction" (Caughley 1994). Extinction theory typically identifies three "stochasticities" that should be considereddemographic, genetic, and environmental-and suggests that interactions among these three factors lead to risk at a higher population abundance than would any of the factors alone. In addition, there is concern that depensatory effects could be significant for salmon populations at low abundance (Neave 1953; Ricker 1954; Peterman 1989). These considerations should be included in establishing any threshold population risk levels; their absence suggests that the total abundance criterion based on $5 N_{e}$ (as suggested by Allendorf et al.) may be too low for adequate protection of individual populations. Also, the points at which demographic and environmental stochasticities and depensatory effects become significant are likely to vary with life history and habitat type, so it is doubtful that a single abundance criterion is appropriate for all stocks. If a single value is used, it should be set high enough to adequately reflect risks for all species in all habitats.

\section{Population Decline}

Allendorf et al. suggest criteria for population decline that are vague and that mix the concepts of trend and abundance. Phrases such as "appear to be stable" or "have previously declined more than known variation would account for" (p. 144) are not particularly useful for assigning a risk level. Also, all three risk levels are referenced with no justification to an annual run size of 500. This combination of trend and abundance criteria is confusing, especially when the annual number of 500 has no apparent relation to the per-generation abundance criteria defined under population size. Either declines should be treated independently of abundance or the two types of information should be combined in a consistent fashion-for example, by defining a "high risk" trend as one that implies a high likelihood of the population dropping below the "very high risk" abundance threshold within a specific time frame.

Short-and long-term trends in abundance are a primary indicator of risk in salmonid populations. Trends in both escapement and (if possible) pre-harvest recruitment need to be considered, as well as trends in factors regulating abundance, such as habitat quantity and quality, environmental conditions, and harvest policies. In addition, the influence of artificial propagation on trends should be considered. When conservation focuses on fish in natural habitats, an important question to ask in evaluating risk is whether natural production is sufficient to maintain the population without the constant infusion of artificially produced fish. When this question cannot be reliably answered, the presence of naturally spawning hatchery fish leads to substantial uncertainty in evaluating the status of the natural population.

In combination with trends, it is important to consider the magnitude of population variability, which is also a main determinant of extinction risk. Variation in freshwater and marine environments may be a primary factor driving fluctuations in run size and escapement (Pearcy 1992; Beamish \& Bouillon 1993; Lawson 1993). Habitat degradation and harvest have probably made stocks less resilient to poor conditions and thus more variable, but these effects are not easily quantifiable.

\section{Conclusions}

Allendorf et al. make a significant contribution by suggesting simple, objective criteria for classifying risk and prioritizing conservation efforts for Pacific salmon. Their proposal, however, falls short of providing a full evaluation of risks. We suggest that the criteria be expanded to include other biological factors important in defining risk to salmon and that the definitions of risk levels be made more consistent across criteria. We also suggest that the proposed reliance on formal model-based PVA be de-emphasized in favor of careful evaluation of the empirical factors contributing to risk.

In our experience, there is no single, easy method for conducting salmonid risk evaluations over broad geographic areas: differences in species biology, natural resource management, and the degree and methods of population monitoring require that different considerations be emphasized for different species and geographic areas. We hope the proposal of Allendorf et al. and our comments will begin a process of reaching a consensus on appropriate methods for both risk assessment and prioritization of recovery and restoration efforts for Pacific salmon. 


\section{Acknowledgments}

The ideas presented in this commentary have been refined within the Endangered Species Act status review group at the Northwest Fisheries Science Center. Colleagues who have had particular influence on some of these ideas include P. Busby, R. Gustafson, J. Hard, O. Johnson, R. Kope, J. Myers, and L. Weitkamp. An anonymous reviewer provided a number of thoughtful comments that improved this response.

\section{Literature Cited}

Allendorf, F. W., and N. Ryman. 1987. Genetic management of hatch ery stocks. Pages 141-159 in N. Ryman and F. Utter, editors. Population genetics and fishery management. University of Washington Press, Seattle.

Allendorf, F. W., D. Bayles, D. L. Bottom, K. P. Currens, C. A. Frissel, D. Hankin, J. A. Lichatowich, W. Nehlsen, P. C. Trotter, and T. H. Williams. 1997. Prioritizing Pacific salmon stocks for conservation. Conservation Biology 11:140-152.

Beamish, R. J., and D. R. Bouillon. 1993. Pacific salmon production trends in relation to climate. Canadian Journal of Fisheries and Aquatic Sciences 50:1002-1016.

Busack, C. A., and K. P. Currens. 1995. Genetic risks and hazards in hatchery operations: fundamental concepts and issues. American Fisheries Society Symposium 15:71-80.

Caughley, G. 1994. Directions in conservation biology. Journal of Animal Ecology 63:215-244.

Gilpin, M. E., and M. E. Soulé. 1986. Minimum viable populations: processes of species extinction. Pages 19-34 in M. E. Soulé, editor Conservation biology: the science of scarcity and diversity. Sinauer Associates, Sunderland, Massachusetts.
Hard, J. J., R. P. Jones, Jr., M. R. Delarm, and R. S. Waples. 1992. Pacific salmon and artificial propagation under the Endangered Species Act. National Oceanic and Atmospheric Administration Technical Memorandum NMFS-NWFSC-2. U.S. Department of Commerce, Seattle.

Hindar, K., N. Ryman, and F. Utter. 1991. Genetic effects of cultured fish on natural fish populations. Canadian Journal of Fisheries and Aquatic Sciences 48:945-957.

Kostow, K., editor. 1995. Biennial report on the status of wild fish in Oregon. Oregon Department of Fish and Wildlife, Portland.

Lawson, P. W. 1993. Cycles in ocean productivity, trends in habitat quality, and the restoration of salmon runs in Oregon. Fisheries 18(8):6-10.

Neave, F. 1953. Principles affecting the size of pink and chum salmon populations in British Columbia. Journal of the Fisheries Research Board of Canada 9:450-491

Pearcy, W. 1992. Ocean ecology of North Pacific salmonids. University of Washington Press, Seattle.

Peterman, R. M. 1989. Review of the components of recruitment in Pacific salmon. American Fisheries Society Symposium 1:417-429

Ricker, W. E. 1954. Stock and recruitment. Journal of the Fisheries Research Board of Canada 11:559-623.

Wainwright, T. C., and R. G. Kope. 1997. Issues and methods of extinction risk assessment for U.S. West Coast salmon. ICES CM 1997/P:16. International Council for the Exploration of the Sea, Copenhagen.

Waples, R. S. 1995. Evolutionarily significant units and the conservation of biological diversity under the Endangered Species Act American. Fisheries Society Symposium 17:8-27.

Washington Department of Fish and Wildlife. 1997. Wild salmonid policy: draft environmental impact statement. Olympia, Washington.

Weitkamp, L. A., T. C. Wainwright, G. J. Bryant, G. B. Milner, D. J. Teal, R. G. Kope, and R. S. Waples. 1995. Status review of coho salmon from Washington, Oregon, and California. National Oceanic and Atmospheric Administration Technical Memorandum NMFS-NWFSC24. U.S. Department of Commerce, Seattle.

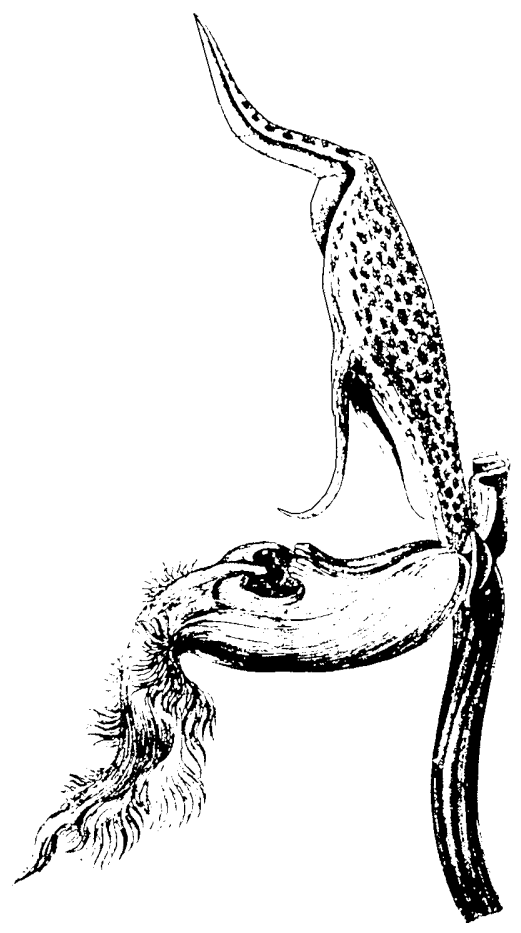

